\title{
Buying Policies of College and University Libraries
}

Dr. van Patten is director of libraries, Stanford University.

$\mathrm{U}$

NLESS a library has a well-formulated buying policy its development is likely to proceed along lines determined by the demands which are made upon it from day to day. The results of such a practice are rarely good.

No two college or university libraries are enough alike to make it possible to establish a policy which would apply equally to all such libraries. Only the factors which underlie the setting up of a buying policy in a college or university library are considered in this paper. These factors have to do with what and where to buy.

The views. expressed are the writer's own and they are submitted for such critical consideration as they may deserve. No use has been made of a questionnaire. Data collected by such means have little value. The result is usually a statistical statement which sets forth how many libraries do a specific thing one way and how many do it in another. There certainly is no reason for assuming that the practice of the majority is right. The best practice may not even be suggested by the answers to a questionnaire.

The conclusions reached here are the result of twenty-one years of experience in the buying of books and periodicals for college and university libraries and eight years of experience in wholesale and retail bookselling. The practices recommended are not necessarily those of the libraries with which the writer has been connected.

State and municipal institutions are usually required to conform to procedures established by statutes or administrative orders. It is obvious that such restrictions largely determine how and where books and periodicals shall be bought and may to a certain extent determine what is to be bought.

There are too many colleges and universities in the United States. The tendency is to increase rather than to decrease the number of such institutions. This is apparent in the wide-spread development during recent years of junior colleges and the establishment of additional state and municipal agencies for higher education.

The increasing number of state and municipal agencies for higher education is largely due to the widely held opinion that young men and women have a right to receive a higher education at public expense. If such an opportunity were provided only for the superior student no one could well take exception to it. The availability of state and municipal institutions to almost every young person who has been able to complete a high school course, the social prestige believed to accompany the possession of an academic degree, and the unhappy idea that a college education increases the earning capacity of the indi- 
vidual have resulted in a flood of students which the taxpayer finds it increasingly difficult to finance, the teaching profession to educate, and the economic life of the country to absorb.

A college or university may expand its teaching and research activities only to find that it possesses neither the laboratory nor library resources necessary to the successful carrying out of its new program. In many fields an adequate library is the sine qua non for good teaching and research. If such a library does not exist at a particular institution it should either limit its work or face the fact that each expansion of the teaching or research activity must be accompanied by a corresponding and expensive expansion of library resources.

The world's literature is now so large that no single library can have more than a small part of it.

\section{Small College Collections}

The library of a small college should be limited to a well-selected reference collection, standard works of literature, and the essential books and periodicals for its teaching program. The activities of a small college should not be expanded with the idea that its library deficiencies may be made up by depending upon the resources of other institutions.

The legitimate interlibrary loan is based upon a recognition that there must be a pooling of resources. It never should take the character of a relationship between host and parasite.

The larger college or university library, within the limits of its budget, must go beyond the boundaries set by the teaching and research activities of the supporting institution. Such a library may be expected to become a great storehouse for the accumulated knowledge of the past. There is no other agency, aside from a few endowed libraries not connected with educational institutions and the great public libraries, which can be expected to meet this responsibility.

The budget of a large college or university library should provide funds for:

I. The purchase of material needed in connection with the institution's current teaching program. This item in the budget should, as a matter of equity, bear some relationship to the income derived from tuition charges. There will be relatively little increase in the permanent resources of a library from such expenditures.

2. The purchase of material needed in connection with the work of the institution's research agencies and the individual studies of members of the staff. This item should largely represent income derived from grants made by the learned foundations and from general endowments.

3. The purchase of material needed to strengthen the resources of the library without specific reference to the institution's current teaching and research activities. This item should represent income from special library endowments, gifts, and a share of the institution's general income.

4. The purchase of current literature for general cultural reading, the extracurricular activities of students, and amusement. This item should represent income from a library fee collected for this purpose.

The selection of material for current teaching must obviously be carried out in close cooperation with the teaching staff. Determining factors include the nature of the subject, the extent of the literature, the method of teaching, and the number of students enrolled for a particular course. 
The selection of material needed in connection with research must largely rest with the individuals who are to make use of it.

The selection of current literature for general cultural reading and amusement should rest with the individuals who provide funds for such purchases. Some anticipation of the demand for popular literature will be generally appreciated.

The librarian and his associates are particularly concerned with the purchase of material needed to strengthen the resources of the library without regard to an institution's current teaching and research activities.

\section{Status of Librarian a Factor}

The status of the librarian is of fundamental importance in the development of a college or university library. He should not be looked upon merely as an administrative officer. When the librarian has the status of a full professor with all of the accompanying rights and privileges he is placed in a position which makes it possible for him to do creative work. As the academic equal of the professors who are engaged in teaching and research the librarian should be ex officio a member of those committees which are concerned with the curriculum, graduate study, research, and publications. Such an arrangement permits him to anticipate the library needs of the teaching and research departments and to present the library aspects of proposed changes in and expansions of the teaching and research programs. The librarian should be freed from the burden of trying to provide, from a static budget, facilities for the carrying out of new teaching and research programs in the establishment of which he has not had a consultative part.
In most college and university libraries the book fund is divided among the various teaching departments. The basis for the division probably remains a mystery to those concerned. These departmental allotments tend to become static. It is extremely difficult to convince any department that its allotment should be reduced and unless new funds become available it is equally difficult to increase the allotment of a department which has increased needs since this must be done at the expense of other departments. It is a much more satisfactory arrangement to have a single book fund from which all purchases are made and to place the responsibility for the control of this general fund in the hands of the librarian. This prevents waste and makes it possible to meet the varying requirements of the departments without the necessity of frequent and irritating changes in the size of allotments. Such changes are often made without an adequate study of the basis for the increase or decrease.

A large college or university library should provide the materials needed for teaching and research. This is not enough to make it a truly great library. As a center for the cultural life of the academic community its resources should be developed so that it has well-selected collections relating to all of the subjects which are of interest to educated men and women. It must also be recognized that scholars are concerned with library resources rather than with the resources of a single library. This implies an obligation to strengthen its collections so that its resources supplement those of other libraries.

\section{Rare Books}

There is a difference of opinion as to whether or not libraries should acquire 
rare books in competition with private book collectors. The small library cannot do this to any extent while the larger library without access to special funds provided for the purpose probably should not. If a book is both a rare book and an essential book then the library should acquire it if it can afford to do so. Many rare books reach libraries as gifts. The library cannot control the character of such acquisitions except to a limited degree. It is a slow process to build up a notable collection in any special field by waiting for the gift of rare items in that field. Only the largest libraries can afford to purchase items of museum value from current income. An effort should be made to establish contact with individuals who are enough interested in the library to provide funds for extraordinary acquisitions which the librarian desires to make.

\section{Maps and Prints}

Manuscripts may be the finest type of material for research in certain fields. In the purchase of manuscripts preference should be given to the acquisition of unpublished material which may otherwise be lost to scholars.

Very few college or university libraries are justified in the extensive acquisition of maps and prints. Unless such material meets a definite need acquisitions in these fields should be limited to items of immediate use to the reference department. Scholars have access to highly developed collections of maps and prints in large general libraries and in the libraries of museums and societies.

There is no place in the American library world for a competitive spirit except as this may be directed toward an excellence of administration and resources. If one library has a complete file of an important journal or a copy of some rare book the acquisition of a second file or copy is seldom justifiable for a library in the same area. The expense involved in the purchase of the duplicate might better be incurred in the purchase of material not already available. This principle is widely recognized. It cannot be consistently practiced until there are more regional union catalogs and a closer degree of cooperation among individual libraries.

\section{Current Books}

The sole purpose of modern advertising is to sell. This purpose is carried out with great skill and every advantage is taken of the potential buyer by extravagant claims as to the merits of the merchandise offered. This is as true of books and periodicals as it is of automobiles and cigarettes. There is a tendency shared by librarians and members of the teaching and research staffs to buy current books to an extent which leaves little or nothing for the purchase of older works. It would probably be wise in many fields to limit the amount to be spent for current books to approximately 25 per cent of the funds available. This would make it necessary to exercise more careful judgment in the selection of titles for purchase.

Libraries should systematically survey their holdings and establish desiderata lists representing lacunae to be filled. This can be done to a greater extent each year with the help of authoritative bibliographies.

Libraries are not ipso facto entitled to a discount upon their purchases. The library discount represents a trade practice based upon a recognition of the importance to publishers and booksellers of the large purchasing power of libraries and the fact that on library sales there is little or no 
loss due either to poor credit or slow payment.

A library discount of from Io per cent to 20 per cent increases the purchasing power of a library to the same extent. A librarian should not seek to obtain excessive discounts. Such discounts are ordinarily obtained at the expense of other libraries and may be given unwillingly by the publisher or bookseller solely to retain an account.

Librarians have been unwilling to recognize that the library may be detrimental to the welfare of publishers and authors. Many Americans have come to look upon books as something which should be provided at public expense. In this there has been an anticipation of a prevalent opinion now held by many worthy individuals that everything should be supplied at public expense.

The library copy of a current book frequently is read by fifty or more potential buyers. As a matter of equity libraries might be charged a larger price than the private buyer. This is of course impracticable. The principle has been recognized, however, in the sale of bibliographical works to libraries upon a service basis which is supposed to result in each library paying for its copy of a particular work a price determined by the probable use of that work.

A few journals are also supplied to libraries at a higher subscription price than the one charged individual subscribers.

Libraries obtain most of their acquisitions through one or more of the following sources: retail booksellers, publishers, wholesale booksellers, antiquarian booksellers, and subscription agencies.

Some of the advantages and disadvantages peculiar to each of these sources are summarized in the following paragraphs.

\section{Retail Booksellers}

Although the ability of local booksellers to serve the libraries of their communities differs widely, in general, retail booksellers are not a satisfactory library source for books and periodicals.

The local bookseller certainly should be given an opportunity to supply books which he has in stock and is willing to sell upon terms as favorable as those available elsewhere. The bookseller is a community asset and should be given every possible encouragement and support. The greater part of the books purchased by a large college or university library, however, is not likely to be carried in stock by local booksellers. The proper conduct of a bookselling enterprise which supplies libraries requires adequate capital and extensive experience.

The librarian should be cautious in placing orders with a bookseller who offers a discount larger than the one prevalent in the trade. When a discount of 25 per cent or more is offered the gross profit is usually not sufficient to meet expenses and the accumulated deficit will finally result in the failure of the bookseller and serious losses to the publishers who have been supplying their publications to libraries through his agency.

\section{Publishers}

The publisher may offer a larger discount than the wholesale or retail bookseller. If a publisher gives a 40 per cent discount to the bookseller and sells to libraries at a 25 per cent discount he obviously makes a better immediate profit when he sells directly to the latter. If a publisher wishes to enter into competition with the bookseller in the sale of his books it is probably no concern of the librarian. 
The publisher cannot expect that the bookseller will show much enthusiasm in either stocking or selling his books under such circumstances. This is in the long run disadvantageous to many libraries.

The increased discount upon purchases made from the publisher may be more apparent than real. Banks have recently made careful studies of the cost of handling a single check or deposit. It has been found that each transaction costs from ten to twenty-five cents. It is unlikely that the cost of issuing a requisition, handling an invoice, or making a remittance can be much less. It is much more in the libraries with whose costs I am familiar.

In certain areas it is greatly to the advantage of libraries to have access to complete stocks at the local branches of eastern publishing houses. A few publishers do maintain stocks on the Pacific coast. Their enterprise should be rewarded by the patronage of western libraries. This is particularly desirable since there are no large general stocks of books upon the shelves of wholesalers specializing in library business in this area.

Some libraries place all of their orders for current books with publishers and then expect wholesale booksellers to handle for them the purchase of government documents, society publications, and textbooks, upon which little or no profit can be made.

Only a few of the larger libraries are able to carry on transactions with foreign publishers satisfactorily. This is less true of England and Germany than of Latin America, Asia, or the minor European states. Much time is lost in placing orders with a foreign publisher if instead of the books a request is received to make payment in advance or shipments are tied up in the customs.
Publishers in the more out-of-the-way parts of the world know little about the financial responsibility of American institutions. Requisitions in an unfamiliar language are frequently misinterpreted, resulting in costly errors. Transportation charges on one or a few items are relatively high. Customs formalities are annoying. Remittances are difficult to make.

Libraries carrying on business directly with publishers in certain countries, e.g., Russia and Brazil, have probably been unable to get their accounts in balance for years. Every remittance made in terms of American currency has been either too large or too small when exchanged into its foreign equivalent.

\section{Wholesale Booksellers}

There are a number of wholesale booksellers in the United States and abroad who make a specialty of handling library business. Only the larger libraries can maintain order departments equal in equipment and efficiency to the facilities provided by these firms.

These wholesale booksellers are undoubtedly the best sources for books available to college and university libraries large and small.

The relationship between the library and the wholesale bookseller should take on the character of a principal and agent relationship. If the wholesale bookseller gets a major part of a library's profitable business in current trade publications he is usually quite willing to handle orders for material upon which he makes little or no profit. The wholesale bookseller is also prepared to care for continuations, to search for out-of-print items, pay society memberships, purchase government documents, and perform many other valuable services for a good customer. 
There is a substantial saving in concentrating a library's purchases with one agency. Requisitions cover a hundred or more items instead of one or two. Invoices likewise are correspondingly less in number. A single remittance made monthly takes care of many invoices. Adjustments are more readily made.

\section{Antiquarian Booksellers}

It is advantageous for a college or university library to receive the catalogs issued by antiquarian booksellers. If a particular antiquarian bookseller shows an intelligent interest in his offers of desirable items and his catalogs are of permanent value the library should deal directly with him. Scattered items from the catalogs of other dealers should be placed with the library's regular agent who usually can supply much material at the same price since he obtains a small discount on his purchases from these dealers.

\section{Subscription Agencies}

There is likely to be little difference of opinion among librarians as to the desirability of handling all subscriptions through the agencies which specialize in library business. One experience with any other source of supply is usually enough to convince even the most venturesome.

In recent years a number of colleges and universities have made most of their purchases through college or university bookstores. When these campus bookstores have been long established and the library business represents only a small part of their total business the arrangement may be a legitimate one. When a dummy bookselling enterprise is established for the purpose of obtaining excessive discounts the arrangement is certainly open to question upon ethical grounds. Publishers would be entirely justified in refusing to sell to such organizations. A library may be entitled to the prevalent library discount. It is not entitled to a wholesale discount obtained by subterfuge.

The development of any library is in large part the result of a well-formulated policy with regard to what is acquired. Many more books may be bought from available funds if there is an equally wellformulated policy with regard to the channels of acquisition.

\section{Discussion}

Thomas P. Fleming, librarian, Medical Library, Columbia University, commented on Dr. van Patten's paper:

Dr. van Patten has presented a paper which admirably stresses the fundamentals of a sound buying policy, and I agree with him wholeheartedly. I shall not take the time to reiterate what he has said, even though I should like to do so for additional emphasis. There are, however, a few points mentioned with which I personally disagree.
In regard to the matter of allotments to departments, there is something to be said on the other side. The previous paper proposes that there be a single book fund under the control of the librarian, in place of departmental allotments. This proposal may work well in some institutions, but in others it will certainly cause unnecessary bickering and hard feelings. I have been associated with two universities where such a scheme was in operation. In one, it resulted in dissatisfaction, for some departments tried to spend all the money, and it was necessary to curtail their zeal- 
ous activities. In the other university, the situation has been harmonious. The difference in the two universities exists not because of the librarian, but because in the first university, the faculty consistently refused to conform. Where conditions seem to indicate that Dr. van Patten's proposal would not be altogether satisfactory, I suggest the following alternate proposal.

A third university with which I had experience provided for allotments to each department plus a large sum at the disposal of the librarian. This he used to supplement the funds of those departments faced with a genuine need. When it was felt that a department was overstepping its logical demands, the allotment was a good excuse to fall back on.

Dr. van Patten lays down sound principles with reference to the acquisition of rare books. In connection with this, I should like to propose that some association compile a list of reprints and facsimiles of rare books. Such a list would be an excellent guide to the acquisition of these items by some of the smaller institutions.

Dr. van Patten stresses two factors underlying a buying policy, namely, what to buy, and where to buy. To my mind, there is a third factor equally important, which is how to buy. The paper does touch upon this factor in many instances, but I realize that to have covered the subject adequately would have taken more time than that which was allotted. I should like, however, to differ with Dr. van Patten on one point, and to stress further the importance of how to buy as an integral factor in buying policies.

The paper criticizes the practice of libraries in securing excessive discounts. Yet there is another side of the picture. I am sure you all recall the article, "I Can Get It for You Wholesale." So long as the practice is universal, we are not administering our libraries from a sound business point of view if we do not secure as large a discount as possible from reputable dealers.

Securing a justifiable discount is not accomplished by merely asking for it. On the other hand, it requires careful supervision of the placement of orders, and particularly, how they are placed. Some booksellers will tell you that to handle the orders of $X$ University costs them three times as much in clerical help as it does to handle the orders from $\mathrm{Y}$ University. Obviously $\mathbf{X}$ does not get as good a discount as $\mathrm{Y}$. Every large library has on its shelves the national and trade bibliographies of importance. Yet the orders emanating from many of these libraries would lead one to believe that such tools were unknown.

Some libraries consistently ignore the advantages to be gained in holding memberships in certain societies, and still more libraries fail to take advantage of their memberships when they have them. For example, most societies issue books and monographs, or finance their publications by private publishers in addition to the issuance of their own journals, bulletins, proceedings, or transactions. These books and monographs, which they issue or finance, are available to members at a discount far in excess of normal library discounts. Libraries ordering these publications from jobbers generally fail to stipulate that they are members of a particular society, and thereby fail to receive the additional discount.

Dr. van Patten put it mildly when he pointed out that "many more books may be bought from available funds if there is a ... well-formulated policy with regard to the channels of acquisition." 